\title{
Ethnomedicine used for asthma by tribes of Papikondalu forest, Andhra Pradesh, India
}

\author{
O. Aniel Kumar ${ }^{1}$, K. Mallikarjuna², S. S. Durga Prasad ${ }^{2}$, L. Mutyala Naidu ${ }^{1 *}$ \\ ${ }^{1}$ Department of Botany, Andhra University, Visakhapatnam, Andhra Pradesh, India, ${ }^{2}$ Department of Botany, DNR College, \\ Bhimavaram, West Godavari, Andhra Pradesh, India
}

Received: 24.02 .2016

Accepted: 27.03 .2016

Published: 15.04 .2016

*Address for correspondence:

L. Mutyala Naidu, DNR

College, Bhimavaram,

West Godavari - 534 202,

Andhra Pradesh, India.

E-mail: lagudu3@gmail.com

\begin{abstract}
This study represents the information about the treatment of asthma disease by the tribes of Papikondalu forest, Andhra Pradesh, India. A total of 17 medicinal plant species belonging to 17 genera and 14 families were recorded. The documented medicinal plants were labeled alphabetically with their voucher specimen number, family name, vernacular names, parts used, and mode of administration. The documented of these medicinal plants against asthma reveals that these ethnic people are still dependent on local vegetation for their life care. Thus, this type of ethnomedicinal study appears to be useful for the research on medicinal plants for the betterment of humankind.
\end{abstract}

KEY WORDS: Asthma, ethnomedicine, medicinal plants, Papikondalu

\section{INTRODUCTION}

Papikondalu is a breathtakingly beautiful hill range bounded by River Godavari in the state of Andhra Pradesh, India. It is spread across East Godavari, West Godavari, and Khammam districts. The entire area of Papikondalu is covered by tropical rain forests, and it was recently declared as a protected national park. It lies between the $17^{0} 28^{1} 48.39^{11}$ North latitude $81^{0} 29^{1} 16.34^{11}$ Eastern longitude (Figure 1). Papikondalu forest range comprises 12 mandals inhabited by the tribals. The livening tribals are Bagata, Bhil, Chenchu, Gond, Hill Reddi, Jatapu, Kammara, KattuNayakan, Kolam, Konda Dora, Konda Kapu, Kondh, Kotia, Koya, Mukha Dora, Nayak, Pardhan, Porja, Reddi Dora, Savara, Lambada, Valmiki, Yenadi, and Yerukula.

Ethnomedicinal studies have reported antiasthmatic plant species in India. However, no such work has been done in Papikondalu. Nowadays, there are many conventional drugs to treat and cure asthmatic attack. However, many asthma patients resort to traditional medicine because of poverty and fewer side effects. The objectives of the study are to provide information on plant species and recipes used in the treatment of asthma, as practiced in the Papikondalu forest region, and to evaluate the degree of phytotherapeutic exploitation on asthma in the study area.

\section{METHODOLOGY}

The survey was carried out during 2012-2014 covered agency areas of Papikondalu forest. Several field trips were organized to administer questionnaires and interviews to traditional healers. The questions were designed to obtain information on their knowledge of asthma, plants used in treating the disease, method of preparation, and mode of administration. Only the recipes that were cited by at least three different informants were retained in the study. The plants were collected, dried, identified, and authenticated. The voucher specimens were kept in the herbarium of the Department of Botany, Andhra University, Visakhapatnam, Andhra Pradesh, India.

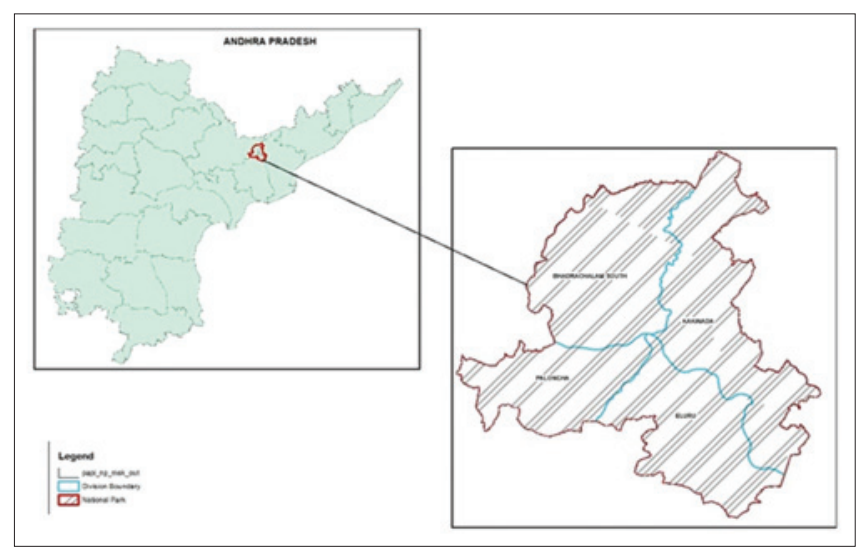

Figure 1: Papikondalu forest area 
Table 1: Antiasthmatic recipes of the Papikondalu forest, Andhra Pradesh

\begin{tabular}{|c|c|c|c|}
\hline Plant name & Common name & Family & Mode of administration \\
\hline Achyranthes aspera (Figure 2) & Uttareni & Amaranthaceae & $\begin{array}{l}\text { Whole plant ash with seed powder of Calotropis gigantea and lemon } \\
\text { juice ground in equal proportions to paste to make pills of groundnut } \\
\text { seed-size. Two pills administered daily twice for a fortnight }\end{array}$ \\
\hline Adhatoda zeylanica & Addasaram & Acanthaceae & $\begin{array}{l}\text { Leaf is ground along with root paste of Solanum surattense and } \\
\text { black pepper in equal quantities and administered in } 10 \mathrm{~g} \text { twice a } \\
\text { day for } 15-30 \text { days }\end{array}$ \\
\hline Aegle marmelos & Maredu & Rutaceae & $\begin{array}{l}\text { Leaf powder mixed with honey is made into soap nut seed size pills } \\
\text { and one pill is administered once a day till cure }\end{array}$ \\
\hline Albizia lebbeck & Dirisena & Mimosaceae & $\begin{array}{l}\text { Stem bark powder mixed with honey is made into ground nut seed } \\
\text { size pills and one pill is administered once a day till cure }\end{array}$ \\
\hline Andrographis paniculata (Figure 3) & Nela vemu & Acanthaceae & $\begin{array}{l}20 \mathrm{ml} \text { of whole plant decoction mixed with one spoonful of long } \\
\text { pepper powder is administered twice a day for } 10 \text { days }\end{array}$ \\
\hline Argemone mexicana (Figure 4) & Brahma dandi & Papaveraceae & $\begin{array}{l}5 \mathrm{~g} \text { of root powder mixed with a cup of water is administered twice } \\
\text { a day for } 7 \text { days }\end{array}$ \\
\hline Barleria prionitis & Gobbi & Acanthaceae & $\begin{array}{l}\text { Two spoonful of whole plant decoction mixed with one spoonful of } \\
\text { black pepper powder is administered twice a day for } 7 \text { days }\end{array}$ \\
\hline Biophytum sensitivum (Figure 5) & Pulichinta & Oxalidaceae & $\begin{array}{l}\text { Handful of leaves is ground with } 5 \text { seeds of Piper nigrum. Two } \\
\text { spoonful of juice is administered daily twice for } 10 \text { days }\end{array}$ \\
\hline Breynia retusa & Chinna purugudu & Euphorbiaceae & $\begin{array}{l}10 \mathrm{ml} \text { of root juice mixed with one spoon of black pepper powder is } \\
\text { taken twice a day till cure }\end{array}$ \\
\hline Caesalpinia pulcherrima & Puvvu tangedu & Caesalpiniaceae & $\begin{array}{l}20 \mathrm{ml} \text { of leaf decoction mixed with half spoonful of dried ginger } \\
\text { powder is administered twice a day for } 10 \text { days }\end{array}$ \\
\hline Calotropis gigantea (Figure 6) & Tella jilledu & Asclepiadaceae & $\begin{array}{l}\text { Two spoonful of flower paste mixed in a glass of hot water } \\
\text { administered daily twice for } 10 \text { days }\end{array}$ \\
\hline Coriandrum sativum & Dhaniyalu & Apiaceae & $\begin{array}{l}\text { Three spoonful of seed juice mixed with one spoonful of long pepper } \\
\text { powder is administered twice a day till cure }\end{array}$ \\
\hline Euphorbia hirta (Figure 7) & Reddi vari nani balu & Euphorbiaceae & $\begin{array}{l}2 \mathrm{~g} \text { of paste of whole plant mixed with leaves of Calotropis procera } \\
\text { and Piper bet/e is taken orally once a day till cure }\end{array}$ \\
\hline Gardenia gummifera & Bikki & Rubiaceae & $2 \mathrm{~g}$ of gum paste is taken orally thrice a day till cure \\
\hline Grewia tiliaefolia & Tene chettu & Tiliaceae & $\begin{array}{l}\text { One spoonful of stem bark decoction is administered with one spoon } \\
\text { of honey twice a day till cure }\end{array}$ \\
\hline Solanum surattense & Vakudu & Solanaceae & $\begin{array}{l}\text { Root is heated on fire and a decoction is prepared and administered } \\
\text { in two spoonful dose thrice a day for } 10 \text { days }\end{array}$ \\
\hline Vanda spathulata & Nusti badanika & Orchidaceae & $\begin{array}{l}10 \mathrm{~g} \text { of flower powder mixed with one spoon of dried zinger powder } \\
\text { along with a cup of water is taken twice a day till cure }\end{array}$ \\
\hline
\end{tabular}

\section{RESULTS AND DISCUSSION}

A total of 17 plant species were explored which have potent use in the treatment of asthma disease (Table 1). These 17 species belong to 17 genera and 14 families of plants. Statistically, among the different plant parts used for the treatment of asthma, the leaves and whole plant of 4 species each, 3 plant species used as root, 2 species each for flowers and stem bark, and one species each for gum and seeds. The parts of 6 plant species were administered in the form of decoction, powder of 4 plant species, paste and juice were 3 species each, and ash of one species was used by the tribal communities for the treatment of asthma.

In this study, 17 medicinal plants belonging to different families were found to be used by tribals in traditional medicine system for the treatment of asthma disease. Although whole plant, flower, seed, gum, root, stem bark, leaves are used, leaves and whole plant are the most common parts used in the treatment of asthma. Many of the preparations are used orally in the form of infusion, decoction, paste, or powder. To our knowledge, this is the first systematic survey on asthma disease in the Papikondalu forest, Andhra Pradesh, India.

From this account, it is clear that the tribals, as in the case of other ancient tribals (Rajasingh, 1971), possess the ability to discern the character of various plants and their beneficial properties for asthma disease. It is interesting to note that such a way of life, particularly with respect to health care practices, has hardly undergone any change even to the present day. Similar ethnomedicinal studies have been reported in some other parts of India (Jain, 2004; Singh, 2004; Muthukumarasamy et al., 2003a and b; 2004a and b; Aniel Kumar et al., 2015), as well as in other parts of the world (Grierson and Afolayan. 1999; Shinwari and Khan, 2000; Suresh et al., 2012).

The knowledge about the use of herbal medicine gradually perishes, although some of the traditional tribal communities and some human beings which believed in the usage of herbal medicines are still practicing the art of herbal healing effectively (Raju, 1995). This study 


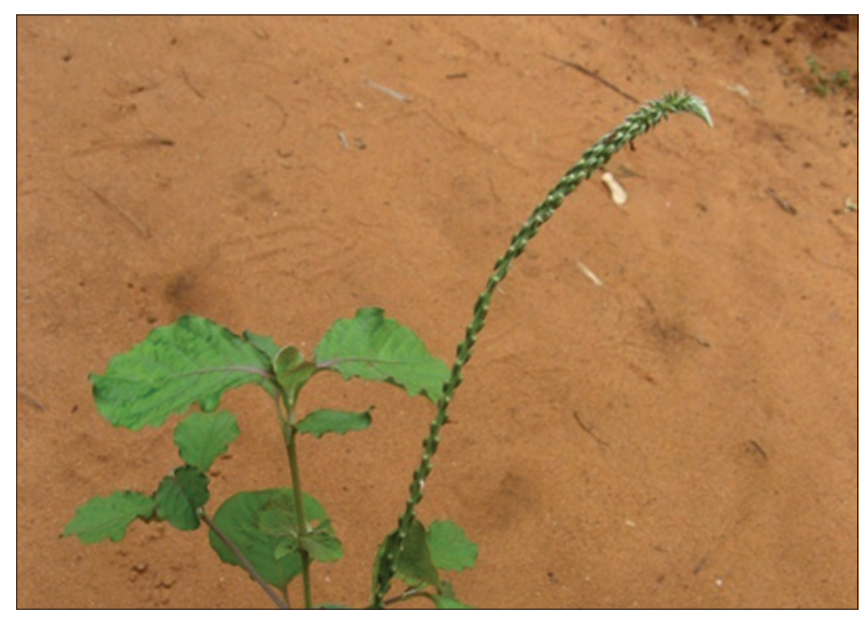

Figure 2: Achyranthes aspera

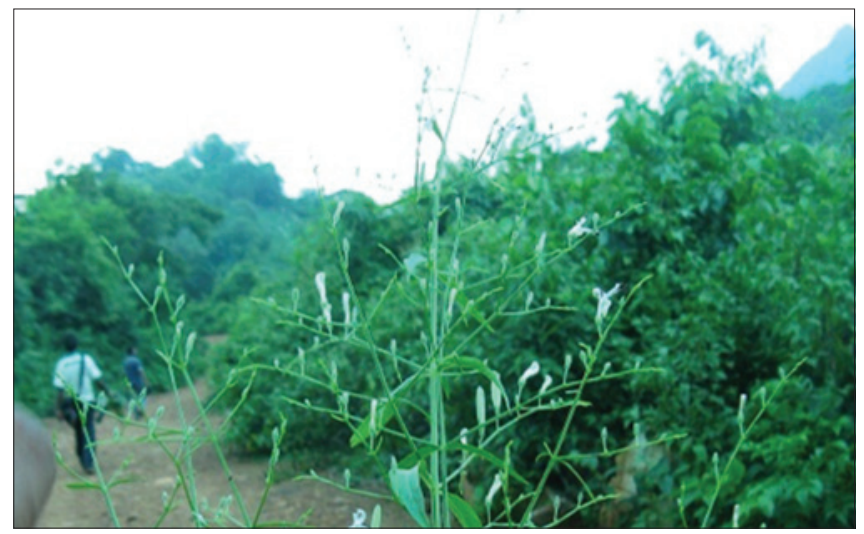

Figure 3: Andrographis paniculata

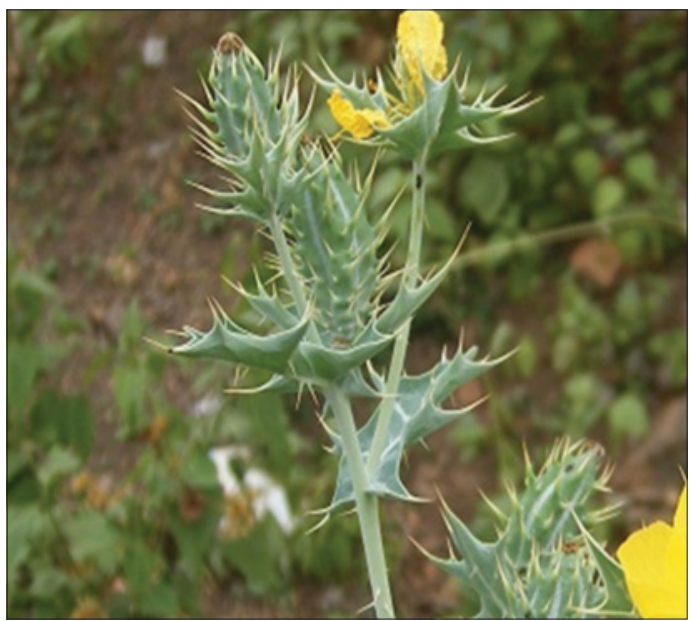

Figure 4: Argemone mexicana

documented the usage of plant species by various tribal communities in Papikondalu forest, Andhra Pradesh, India, for the treatment of asthma. The knowledge about the ethnomedicinal uses of these plant species and their status of distribution in India would be helpful in exploring these plant resources on a large scale. These traditional plant

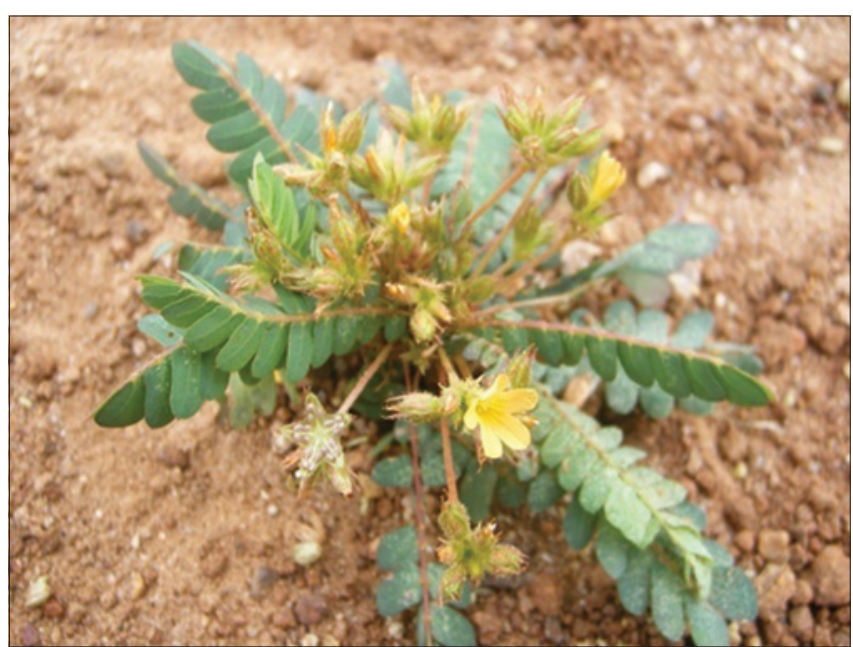

Figure 5: Biophytum sensitivum

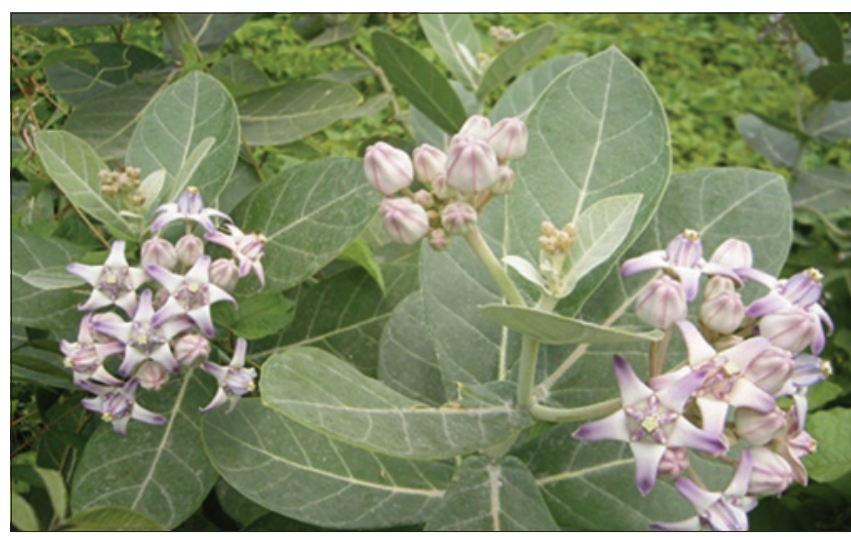

Figure 6: Calotropis gigantea

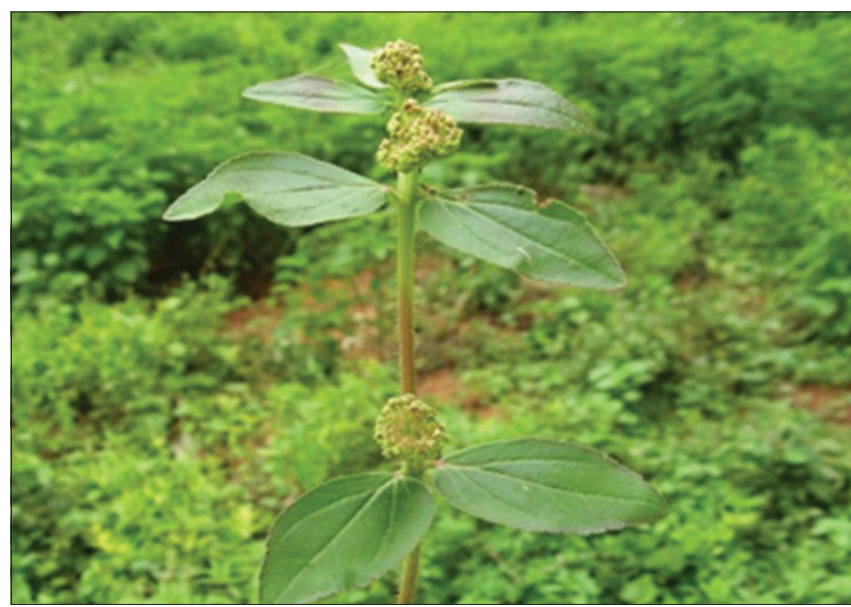

Figure 7: Euphorbia hirta

resources are under great demand by the pharmaceutical industries, for which they extracted several bioactive compounds for the preparation of novel drugs. Likewise, this study would be explored by the common for the treatment of asthma in an herbal way. Therefore, it is concluded that being more dependent on allopathic 
medicines in the form of ethnomedicine by human beings would play a key role in the treatment of asthma in India.

\section{ACKNOWLEDGMENTS}

We are grateful to UGC for providing financial assistance.

\section{REFERENCES}

Aniel Kumar O, Mallikarjuna K, Naidu ML. Ethnomedicine for rheumatoid arthritis by tribes of Papikondalu forest, Andhra Pradesh, India. Am J Ethnomed 2015;2:373-8.

Grierson DS, Afolayan AJ. An ethnobotanical study of plants used for the treatment of wounds in the Eastern Cape, South Africa. J Ethnopharmacol 1999;67:327-32.

Jain SP. Ethno-medico-botanical survey of Dhar district, Madhya Pradesh. Indian J Non-Timber Forest Prod 2004;11:152-7.

Muthukumarasamy S, Mohan VR, Kumaresan S. Herbal medicinal plants used by Palliyars to obtain relief from gastro-intestinal complaints. J Econ Taxon Bot 2003a;27:711-4.

Muthukumarasamy S, Mohan VR, Kumaresan S. Herbal remedies of Palliyar tribe of grizzled giant squirrel sanctuary, Western Ghats, Srivilliputhur, Tamil Nadu for poisonous bites. J Econ Taxon Bot 2003b;27:761-4.

Muthukumarasamy S, Mohan VR, Kumaresan S. Medicoethnobotany of Palliyar tribe in grizzled giant squirrel wild life sanctuary, Srivilliputhur, Western Ghats, India. J Med Aromat Plant Sci 2004b;26:507-16.

Muthukumarasamy S, Mohan VR, Kumaresan S. Traditional medicinal practices of Palliyar tribe of Srivilliputhur in ante-natal and post-natal care of mother and child. Nat Prod Radiance 2004a;3:422-6.

Rajasingh GJ. Forest Working Plan for Tirunelveli North Division. Madras: Government of Madras Publication; 1971. p. 127-33.

Raju MS. Unreported medicinal uses of some plants of East Godavari district of Andhra Pradesh. Vanyajati 1995;14-7.

Shinwari MI, Khan MA. Folk use of medicinal herbs of Margalla Hills National Park, Islamabad. J Ethnopharmacol 2000;69:45-56.

Singh KS. Ethnomedicinal plants of Kallu Valley, Himachal Pradesh (India). J Non-Timber Forest Prod 2004; 11:74-9.

Suresh M, Ayyanar M, Amalraj L, Mehalingam P. Ethnomedicinal plants used to treat skin diseases in Pothigai hills of Western Ghats, Tirunelveli district, Tamil Nadu, India. J Biol Sci Res 2012;3:112-21. 